\title{
Differential Regulation of Mouse B Cell Development by Transforming Growth Factor $\beta 1$
}

\author{
DENISE A. KAMINSKI ${ }^{\mathrm{a}, *}$, JOHN J. LETTERIO ${ }^{\mathrm{b}}$ and PETER D. BURROWS ${ }^{\mathrm{a}}$, $^{\dagger}$
}

${ }^{\mathrm{a}}$ Department of Microbiology, 378 Wallace Tumor Institute, The University of Alabama at Birmingham, Birmingham, AL 35294, USA; ${ }^{\mathrm{b}}$ Laboratory of Cell Regulation and Carcinogenesis, The National Cancer Institute, 41 Library Drive, Bethesda, MD 20892, USA

(Revised 4 January 2003)

\begin{abstract}
Transforming growth factor $\beta$ (TGF $\beta$ ) can inhibit the in vitro proliferation, survival and differentiation of B cell progenitors, mature B lymphocytes and plasma cells. Here we demonstrate unexpected, agedependent reductions in the bone marrow (BM) B cell progenitors and immature $\mathrm{B}$ cells in TGF $\beta 1^{-/-}$ mice. To evaluate TGF $\beta$ responsiveness during normal B lineage development, cells were cultured in interleukin 7 (IL7) \pm TGF $\beta$. Picomolar doses of TGF $\beta 1$ reduced pro-B cell recoveries at every timepoint. By contrast, the pre-B cells were initially reduced in number, but subsequently increased compared to IL7 alone, resulting in a 4-fold increase in the growth rate for the pre-B cell population. Analysis of purified BM sub-populations indicated that pro-B cells and the earliest BP1 ${ }^{-}$pre-B cells were sensitive to the inhibitory effects of TGF $\beta 1$. However, the large $\mathrm{BP} 1^{+}$pre-B cells, although initially reduced, were increased in number at days 5 and 7 of culture. These results indicate that TGF $\beta 1$ is important for normal B cell development in vivo, and that B cell progenitors are differentially affected by the cytokine according to their stage of differentiation.
\end{abstract}

Keywords: B cell progenitor; Bone marrow; IL7; Pre-B cell; Pro-B cell; TGF $\beta$

Abbreviations: BM, bone marrow; HC, antibody heavy chain; $\mathrm{BCP}, \mathrm{B}$ cell progenitor; TGF $\beta$, transforming growth factor $\beta$; IL7, interleukin 7; LM, littermate

\section{INTRODUCTION}

Transforming growth factor $\beta$ (TGF $\beta$ ) is distinguished among cytokines in its involvement in multiple biological processes, eliciting unique responses according to context (Massague et al., 1992; Rifkin et al., 1993; McCartneyFrancis and Wahl, 1994; Bottinger et al., 1997). Its overlapping functions include regulation of embryogenesis (Dickson et al., 1995; Kaartinen et al., 1995; Bonyadi et al., 1997; Sanford et al., 1997), cell cycle and viability (Ravitz and Wenner, 1997; Hocevar and Howe, 1998) and cellular adhesion (Roberts et al., 1992; Wahl, 1994; Kim and Yamada, 1997; Letterio and Roberts, 1998). The interplay of these TGF $\beta$-regulated processes controls the development and function of the immune system (Yaswen et al., 1996; Letterio and Roberts, 1998; Larsson et al., 2001).

Limitations to studying TGF $\beta$ effects in vivo are imposed by its importance during embryogenesis. Gene-targeting of each isoform (TGF $\beta 1,2$ or 3 ) as well as

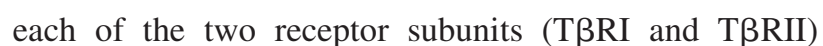
results in lethality at or prior to birth (Dickson et al., 1995; Kaartinen et al., 1995; Martin et al., 1995; Bonyadi et al., 1997; Sanford et al., 1997). The earliest lethality is seen in ${\mathrm{T} \beta \mathrm{RI}^{-1-}}^{-1} \mathrm{~T} \beta \mathrm{RII}^{-1-}$ (Larsson et al., 2001), and in $\sim 50 \%$ of TGF $\beta 1^{-l-}$ embryos (Shull et al., 1992; Kulkarni et al., 1993), which expire at $\sim 10.5$ days post-coitus, due to aberrantly developed yolk sac vasculature and anemia. The embryonic anemia in vivo is likely a secondary result of inadequate vascularization, since endothelia from the TGF $\beta 1$ mutant embryos fail to differentiate in culture (Martin et al., 1995), whereas in vitro development of yolk sac-derived $\mathrm{T} \mathrm{RI}^{-/-}$hematopoietic progenitors into various blood cell lineages is similar to controls (Larsson et al., 2001).

The importance of TGF $\beta$ in immune regulation is underscored by the phenotype of TGF $\beta 1^{-1-}$ mice, which have multiple abnormalities, including systemic inflammation to which they succumb by $3-5$ weeks after birth

*Present Address: Department of Molecular Genetics and Microbiology, University of Massachusetts Medical School, 55 Lake Avenue, Worcester, MA 01655, USA.

Corresponding author. Tel.: +1-205-934-6529. Fax: +1-205-934-1875. E-mail: peterb@uab.edu 
(Shull et al., 1992; Kulkarni and Karlsson, 1993; Kulkarni et al., 1993; Diebold et al., 1995; Kulkarni et al., 1995; McCartney-Francis et al., 1997). The inflammatory disease of TGF $\beta 1^{-1-}$ mice is attenuated when T cells are eliminated, implicating $\mathrm{T}$ cells as a major mediator of inflammation (Kulkarni and Karlsson, 1993; Diebold et al., 1995; Kulkarni et al., 1995; Borkowski et al., 1996; Letterio et al., 1996; McCartney-Francis et al., 1997; Nakabayashi et al., 1997; Kobayashi et al., 1999; McLennan et al., 2000).

Once a hematopoietic progenitor enters the B lineage pathway, it progresses through a number of developmental stages defined by expression of cell surface differentiation antigens (Hardy et al., 1991; Rolink et al., 1999), cell cycle status (Osmond, 1991; Itoh et al., 1996), antibody variable region gene rearrangements (Hardy et al., 1991; Hardy, 1992; Li et al., 1993; Papavasiliou et al., 1997; Rolink et al., 1999), responsiveness to and requirements for interleukin 7 (IL7) receptor signaling (Peschon et al., 1994; Candeias et al., 1997; Marshall et al., 1998) and interaction with the bone marrow (BM) stroma (King et al., 1988; Gimble et al., 1989; Dittel et al., 1993; Dittel and LeBien, 1995; Borghesi et al., 1997). The IL7 receptor is indispensable for mouse B cell development during the V-to-DJ heavy chain (HC) variable region gene rearrangement process (Corcoran et al., 1998). Acquisition of $\mu \mathrm{HC}$ and formation of the pre-B cell receptor are associated with a decreased IL7 dose-response threshold (Marshall et al., 1998). The resulting increases in IL7 sensitivity may be responsible for the large size and mitotic status of early/intermediate pre-B cells. Late pre-B cells exit the cell cycle and undergo light chain $\mathrm{V}-\mathrm{J}$ rearrangement in preparation for full antibody assembly and surface expression on the more differentiated B cell (Meffre et al., 2000; Melchers et al., 2000).

The effects of exogenous TGF $\beta$ have been examined in cultured B lineage cells representative of almost every developmental stage, and are usually inhibitory. Early studies showed that TGF $\beta$ inhibits the proliferative response of BM B cell progenitors (BCP) to IL7, and that it can inhibit $\kappa \mathrm{LC}$ acquisition in a differentiating B lineage cell line (Lee et al., 1987; Kincade et al., 1989). Similar observations have been made for $\kappa$ light chains in human fetal BM cultures (Rehmann and LeBien, 1994). However, these studies did not distinguish the effects of TGF $\beta$ on pro-B versus pre-B cells within one system. Induction of the transcriptional regulator Id 3 by TGF $\beta$, together with inhibition of cell cycling and Rag1 mRNA expression has also been demonstrated (Kee et al., 2001). TGF $\beta$ effects at later mature B and plasma cells stages are almost exclusively negative with the exception of inducing $\operatorname{IgA}$ isotype switching (Kim and Kagnoff, 1990; Lebman et al., 1990; Shockett and Stavnezer, 1991). These studies indicate that TGF $\beta$ can inhibit the in vitro survival, proliferation and differentiation of antibody-producing B cells at all stages of development.

An inhibitory role for TGF $\beta$ in the immune system is supported by the phenotype of juvenile TGF $\beta 1^{-1-}$ mice
(Christ et al., 1994). Infiltrates of plasma cells are found in secondary lymphoid organs and also in non-lymphoid tissues where they accompany inflammatory infiltrates of other hematopoietic cells (Christ et al., 1994; Kulkarni et al., 1995; van Ginkel et al., 1999). The mice also have increased levels of anti-nuclear and anti-collagen serum antibodies (Dang et al., 1995; Yaswen et al., 1996) and hyperproliferation in the splenic B cell follicles (Christ et al., 1994).

These observations, together with the described inhibitory effects of TGF $\beta$ on in vitro B cell development, predicted the expansion of $\mathrm{B}$ cell progenitors in the absence of TGF $\beta$ in vivo. We found instead an age-related deficiency in B cell development in TGF $\beta 1^{-1-}$ mice. The complication of the co-existing inflammatory disease in these mice lead us to re-examine the in vitro effects of TGF $\beta 1$ on defined sub-populations of normal BM B lineage cells. The results of this combined approach indicate that deficiencies in the earliest $\mathrm{B}$ cell progenitors in the TGF $\beta 1^{-1-}$ mice are likely to be due to secondary effects of the phenotype, since pro-B cell growth is inhibited by TGF $\beta 1$ in vitro. By contrast, TGF $\beta 1$ increases the recovery of the large pre-B cells. Collectively, these observations demonstrate that TGF $\beta 1$ is required for normal $\mathrm{B}$ cell development in vivo, and indicate differential sensitivity of $\mathrm{B}$ cell progenitors to TGF $\beta$ according to their stage of differentiation.

\section{MATERIALS AND METHODS}

\section{Flow Cytometry}

TGF $\beta 1^{-1-}$ mice were derived from TGF $\beta 1^{+/-}$crosses as described (Kulkarni et al., 1993). Erythrocyte-depleted $\mathrm{BM}$ cells were recovered from TGF $\beta 1^{-1-}$ mice and agedmatched TGF $\beta 1^{+/+}$littermate controls on a mixed C57BL/6J $\times$ SVJ/129 background. All incubations for flow cytometry were on ice for $15 \mathrm{~min}$, followed by washing with $1 \%$ FBS in PBS. Aliquots of $10^{6}$ cells from each mouse were stained with combinations of fluorochrome-conjugated antibodies specific for CD43 (S7), BP1 (6C3/BP1), HSA (M1/69), Mac1 (M1/70), Thy1.2 (30H12) and B220 (RA3-6B2) from BD Pharmingen (San Diego, CA), IgD (SBA-1) and goat anti-mouse IgM from Southern Biotechnology Associates (Birmingham, AL). Stained cells were analyzed using a Becton-Dickinson FACSCalibur flow cytometer (San Diego, CA). Values from TGF $\beta 1^{+/+}$and $\mathrm{TGF} \beta 1^{-1-}$ mice were compared using a Student's $t$-Test.

\section{Cell Culture}

Erythrocyte-depleted BM from 4- to 5-week-old female C57BL/6 mice was purified by centrifugation over a Lympholyte $\mathrm{M}$ gradient (Cedar Lane, Hornby, Ont., Canada). B220 ${ }^{+}$cells were isolated by positive selection with magnetic beads (Miltenyi, Auburn, CA); sorting 
efficiency was assessed by flow cytometry to be $85 \pm 8 \%$. FACS ${ }^{\circledR}$-sorted cells were purified with a MoFlo flow cytometer (Cytomation, Fort Collins, CO) using antiCD19 (clone 6D5 from Southern Biotechnology Associates, Birmingham, AL), anti-BP1 and anti-IgM (as above). $5 \times 10^{4}$ sorted cells $/ \mathrm{ml}$ were plated in complete IMDM $\left(5 \%\right.$ FCS, $5 \times 10^{-5} \mathrm{M} 2 \mathrm{ME}, 1 \%$ each L-glutamine, penicillin/streptomycin, non-essential amino acids) and treated with $10 \mathrm{ng} / \mathrm{ml}$ recombinant mouse IL7 (PeproTech, Rocky Hill, NJ) \pm recombinant human TGF $\beta 1$ (R and D Systems, Minneapolis, MN). Two doses of $0.04 \mathrm{ng} / \mathrm{ml}$ $(1.6 \mathrm{pM})$ or $1 \mathrm{ng} / \mathrm{ml}(40 \mathrm{pM})$ were compared in all of the experiments shown here because dose-response experiments showed distinct read-outs at these two concentrations. Harvested cells were counted by Trypan Blue exclusion and surface-stained for B220 (as above) and sIgM [goat anti-mouse $\operatorname{IgM}^{\text {cy5 }}$ from Jackson Laboratories (Bar Harbor, ME) or MB86 ${ }^{\text {Alexa647 }}$ from John Kearney (Birmingham, AL)], or control antibodies. These cells were fixed in $1 \%$ paraformaldehyde, permeablized with Tween 20 and stained intracellularly with a goat antimouse $\mu^{\mathrm{F}}$ antibody. For some experiments, the CytoFix/ Cytoperm kit from Pharmingen was used according to the manufacturer's instructions. The pre-B cell growth rate was calculated as (pre-B cell number recovered on day 7 - pre-B cell number recovered on day 3)/4 days $=$ cells/day

\section{RESULTS}

\section{Age-dependent BM B Lineage Cell Reductions in TGF $\beta 1^{-/-}$Mice}

Flow cytometry was used to examine the proportions (Fig. 1A,B) and absolute numbers (Fig. 1C) of B220 ${ }^{+}$B lineage cells in the $\mathrm{BM}$ of neonatal (1.5-week-old) and juvenile (3.5-week-old) TGF $\beta 1^{-1-}$ mice. The 1.5 weekold TGF $\beta 1^{-1-}$ mice were comparable to the TGF $\beta 1^{+/+}$ littermate (LM) controls at the early, $\operatorname{sIgM}^{-}$and later, $\mathrm{sIgM}^{+}$stages. By contrast, 3.5-week-old mice showed a significant 2.6-fold reduction in the percentage of $\mathrm{B} 220^{+} \mathrm{SIgM}^{-}$cells, corresponding to a significant 4.6fold reduction in absolute cell number. Absolute numbers

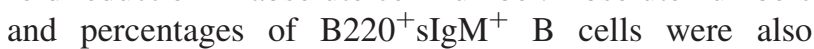
reduced, although not consistently.

The cell surface marker system described by Hardy et al. (1991) was used to further define the B lineage developmental stages affected by the TGF $\beta 1$ deficiency, and the results were calculated both as a percentage of total BM (Fig. 2A,B) and as absolute cell numbers (Fig. 2C). In TGF $\beta 1^{-/-}$mice examined at 3.5 weeks of age, the percentage of cells in Fraction B $\left(\mathrm{B} 220^{+} \mathrm{CD}_{4}{ }^{+} \mathrm{HSA}^{+} \mathrm{BP} 1^{-}\right)$, including pro- and pre-B cells (Wasserman et al., 1997), was not significantly changed, although the absolute numbers of these cells were 2.6-fold reduced. The percentage and absolute number of pre-B cells in Fraction $\mathrm{C}\left(\mathrm{B} 220^{+} \mathrm{CD} 43^{+} \mathrm{HSA}^{+} \mathrm{BP} 1^{+}\right)$
A

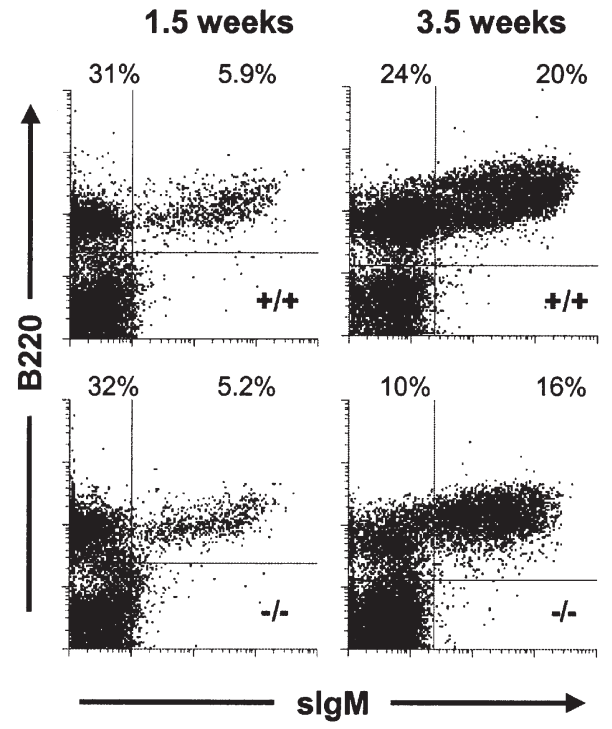

B

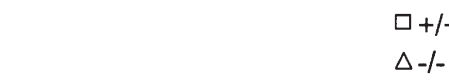

$\mathrm{B220}^{+}$slgM-

$\mathrm{B220}^{+}$slgM ${ }^{+}$
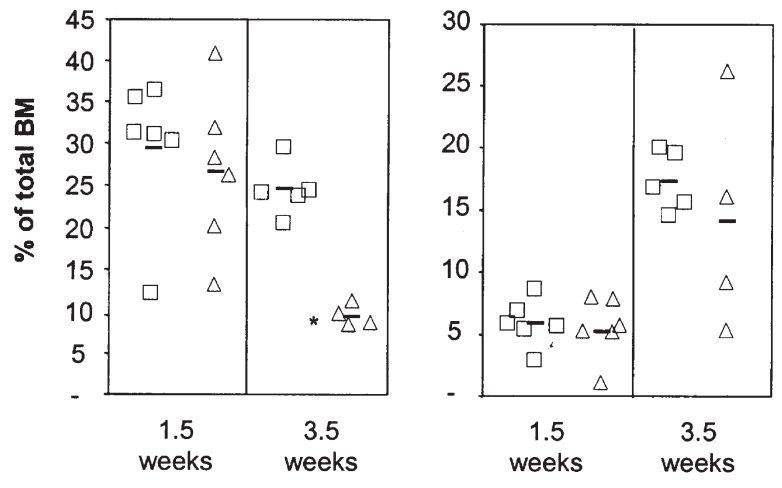

C

$\square+/+$

$\Delta-/-$

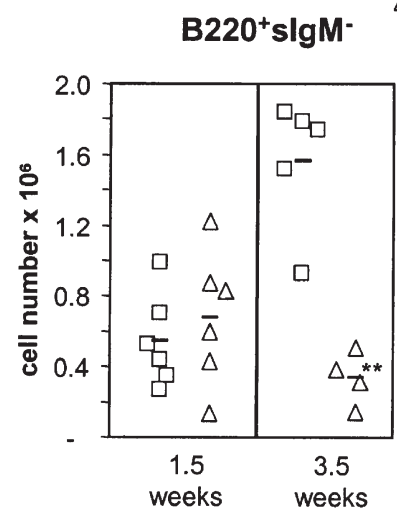

${\mathrm{B} 220^{+}}^{+} \operatorname{sgM}^{+}$

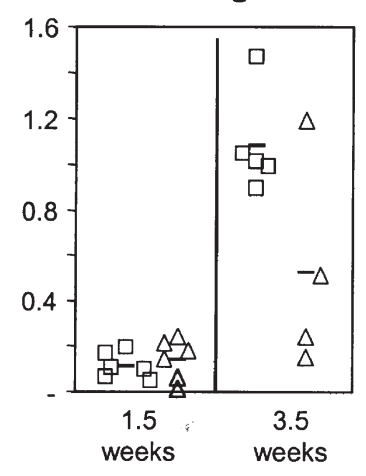

FIGURE 1 B cell development in $\mathrm{TGF} \beta^{-1-}$ mice. BM from $\mathrm{TGF} 1^{-1-}$ mice and age-matched $\mathrm{TGF}^{+/+} 1^{+/ \mathrm{LM}}$ ) controls was prepared for flow cytometry as indicated in "Methods" section. (A) Profiles of gated lymphocytes showing expression of B220 and sIgM. Values indicated are the per cent of total BM. (B) Percentage of total $\mathrm{BM}$ for individual mice. ${ }^{*} p=0.0001$ for the $\mathrm{B} 220^{+} \mathrm{sIgM}^{-} \mathrm{BCP}$ between TGF $\beta 1^{-1-}$ and LM controls. (C) Absolute numbers of cells for the populations shown in A and B. ${ }^{* *} p=0.008$. 
A

B220+CD43+
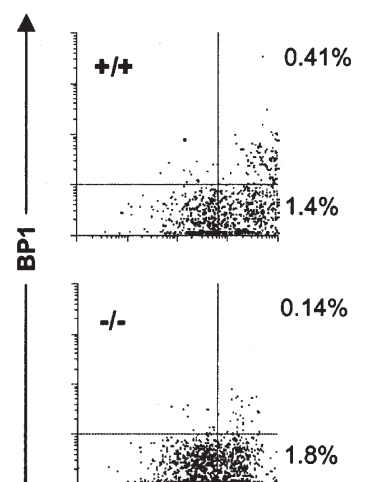

$\longrightarrow$ HSA $\longrightarrow$
B220+CD43.

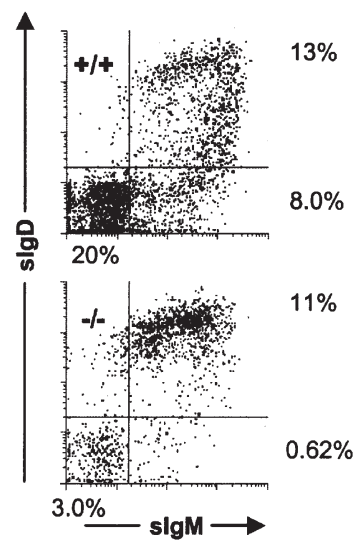

口 +/+

$\Delta-/$

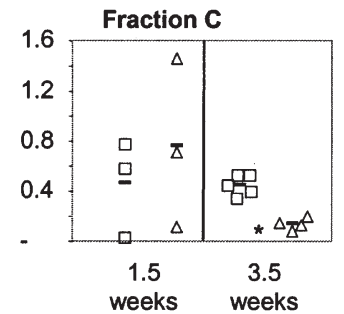

weeks weeks
B

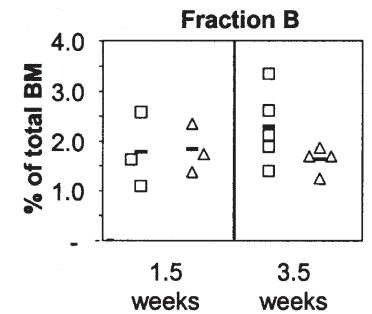

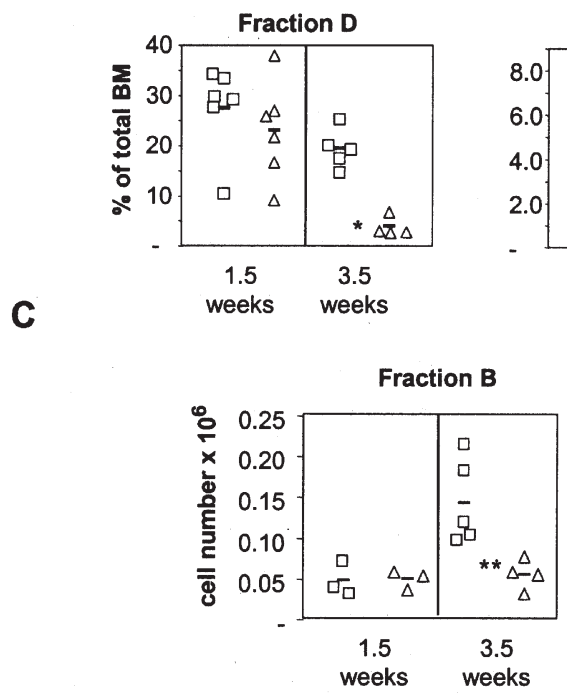

Fraction E
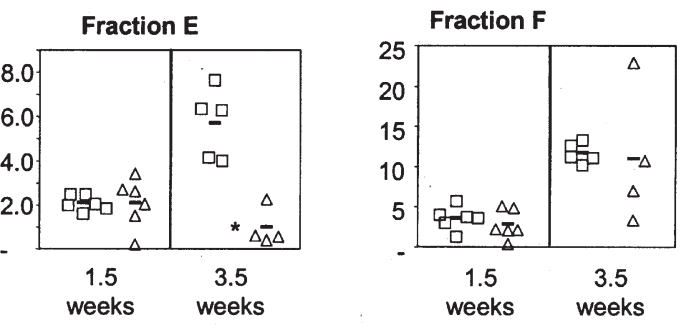

ㅁ/+

$\Delta-/-$

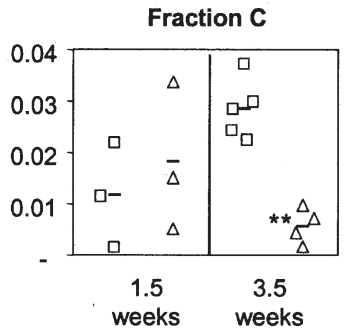

Fraction D

Fraction E

Fraction $\mathrm{F}$
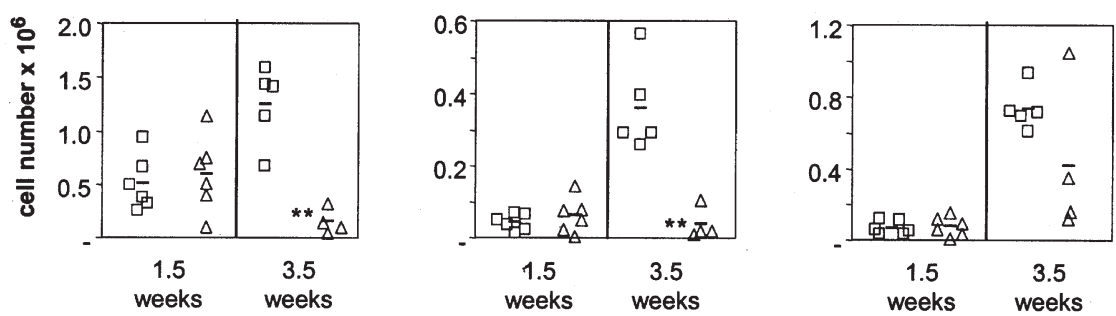

FIGURE 2 B cell progenitor deficiencies in juvenile TGF $\beta 1^{-/-}$BM. BM lymphocytes from 3.5 -week-old TGF $\beta 1^{-1-}$ mice and LM controls were prepared for flow cytometry as in Fig. 1 using the indicated markers. (A) Representative flow cytometry profiles gated on the $\mathrm{B} 220^{+} \mathrm{CD} 43^{+}$or $\mathrm{B} 220^{+} \mathrm{CD} 43^{-}$lymphocyte populations as indicated. Values indicated are the per cent of total BM. (B) Percentage of total BM for individual mice. ${ }^{*} p \leq 0.001$ between TGF $31^{-/-}$and LM controls. (C) Absolute numbers of B lineage cells for mice represented in A and B. ** $p \leq 0.02$ between TGF $\beta 1^{-1-}$ and LM controls. 
TABLE I Frequency* of BM B lineage compartment reductions in TGF $\beta 1^{-1-}$ mice

\begin{tabular}{lccccccc}
\hline & \multicolumn{3}{c}{${\mathrm{B} 220^{+}}$} & & \multicolumn{3}{c}{ B Lineage fraction $\dagger$} \\
\cline { 2 - 6 } Age & $\operatorname{sIgM}^{-}$ & $\operatorname{sIgM}^{+}$ & & $\mathrm{B}$ & $\mathrm{C}$ & $\mathrm{D}$ & $\mathrm{E}$ \\
\hline $1-2$ weeks & $1 / 7$ & $1 / 7$ & $0 / 4$ & $0 / 4$ & $1 / 7$ & $1 / 7$ & $3 / 7$ \\
$>2$ weeks & $10 / 14$ & $3 / 14$ & $7 / 11$ & $10 / 13$ & $11 / 12$ & $9 / 12$ \\
\hline
\end{tabular}

* Number of TGF $\beta 1^{-1-}$ mice with reductions in absolute cell numbers of $\geq 2$-fold compared to LM controls per number of TGF $\beta 1^{-1-}$ mice examined.

$\dagger$ According to (Hardy et al., 1991; Li et al., 1993; Li et al., 1996).

were significantly reduced by $3.0-$ and 5.0fold, respectively. The late pre-B cells in Fraction D $\left(\mathrm{B} 220^{+} \mathrm{CD} 43^{-} \mathrm{IgM}^{-} \mathrm{IgD}^{-}\right.$) were proportionally reduced by 4.6 -fold and in absolute cell number by 8.2 fold. The subsequent immature B cells, Fraction E $\left(\mathrm{B} 220^{+} \mathrm{CD} 43^{-} \mathrm{IgM}^{+} \mathrm{IgD}^{-}\right.$) were proportionally reduced by 5.7 -fold and in absolute number by 9.2 -fold. Mature B cells $\left(\mathrm{B} 220^{+} \mathrm{CD} 43^{-} \mathrm{IgM}^{+} \mathrm{IgD}^{+}\right.$, Fraction $\left.\mathrm{F}\right)$ in the $\mathrm{BM}$ were variably increased or decreased in proportion and in absolute number (Fig. 2C) as was observed in the periphery [not shown and Christ et al. (1994)]. It should be noted that Fraction A $\left(\mathrm{B} 220^{+} \mathrm{CD}_{4} 3^{+} \mathrm{HSA}^{-} \mathrm{BP}^{-}\right)$is not consistently affected in the TGF $\beta 1^{-/-}$mice (Fig. $2 \mathrm{~A}$ and not shown); however, not all the cells in this population are progenitors of the B lineage (Tudor et al., 2000).

In vivo, the reductions seen in Fraction $\mathrm{B}$ were statistically significant when calculated as absolute numbers of cells recovered (2.6-fold), but not as a percentage of total BM cells. This might suggest that Fraction B itself is unchanged, and that the smaller size of the TGF $31^{-l-}$ mice (Shull et al., 1992; Boivin et al., 1995; Kulkarni et al., 1995), and therefore smaller bone cavity, is the cause of this reduction in cell number. However, normalizing the cell number to body weight of each mouse still results in a significant reduction in Fraction B, although the degree of reduction is less, at 1.8fold $\left(+/+, 1.46 \times 10^{4} \pm 4.98 \times 10^{3}\right.$ cells $/ \mathrm{g} ;-/-, 8.08 \times$ $10^{3} \pm 2.27 \times 10^{3}$ cells $\left./ \mathrm{g}, p=0.048\right)$. The reduction in Fraction $\mathrm{C}$, however, is significant regardless of how the data are calculated: as a proportion of total BM (3.0-fold), as an absolute cell number (5.0-fold), and also as a normalized cell number [3.6-fold $\left(+/+, 2.90 \times 10^{3} \pm\right.$ 632 cells $/ \mathrm{g} ;-/-, 810 \pm 463$ cells $/ \mathrm{g}, p=0.00091)]$.

A summary of a more extensive analysis of mice at different ages is shown in Table I as the frequency of $\mathrm{TGF} \beta 1^{-1-}$ mice with reductions of $\geq 2$-fold in the absolute numbers of BM B lineage cells. These mice are not included in Fig. 2 because a different number of bones per mouse were used for the analysis. Although there is some variability, these results confirm the age-dependent decrease in $\mathrm{BCP}$ in the TGF $\beta 1^{-1-}$ mice. The frequencies of mature B cells are reduced in slightly more than half of the mice, which may be due to variable experiences of these recirculating cells in the periphery. Phenotypic variability in TGF $\beta 1^{-1-}$ mice has been noted in other contexts, for example, inflammation in organs other than heart and lung (Shull et al., 1992; Kulkarni and Karlsson, 1993; Boivin et al., 1995; Kulkarni et al., 1995).
Activated $\mathrm{T}$ cells are responsible for much of the characteristic inflammatory phenotype of the TGF $\beta 1^{-1-}$ mouse (Diebold et al., 1995; Kobayashi et al., 1999). To ask whether the BCP reductions in the TGF $\beta 1^{-1-}$ mice were associated with an altered $\mathrm{BM}$ microenvironment, Thy1.2 and Mac1 were used as markers for BM T and myeloid cells, respectively. Although the Thy $1.2^{+}$ population was proportionally increased in all 3.5-weekold mice examined (Fig. 3A), this did not correlate with increased cell numbers in most mice (Fig. 3B). The proportions of $\mathrm{Mac1}^{+}$cells were increased in half of the mice examined (Fig. 3C); however, once again, this generally did not correspond to an increase in the absolute numbers of myeloid lineage cells (Fig. 3D). One explanation for the observed discrepancy between the percentages and absolute cell numbers may again be the smaller size of the TGF $\beta 1^{-/-}$mice (Shull et al., 1992; Boivin et al., 1995; Kulkarni et al., 1995). However, when the data were normalized to body weight, a similar pattern was observed for Thy1.2 $\left(+/+, 1.8 \times 10^{4} \pm 1.1 \times\right.$ $10^{4}$ cells $/ \mathrm{g} ;-/-, 4.4 \times 10^{4} \pm 2.6 \times 10^{4}$ cells $/ \mathrm{g}$ ), and for Mac1 $\left(+/+, 7.5 \times 10^{4} \pm 1.1 \times 10^{4}\right.$ cells $/ \mathrm{g} ;-/-$, $11.1 \times 10^{4} \pm 4.8 \times 10^{4}$ cells $/ g$ ). These findings show that there is an altered cellular composition of the BM in the $\mathrm{TGF} \beta 1^{-1-}$ mice, including changes in the proportions of
A

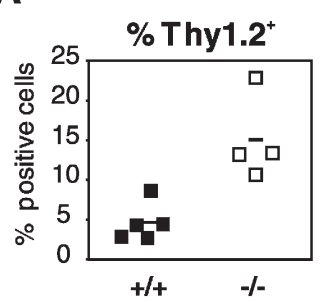

C

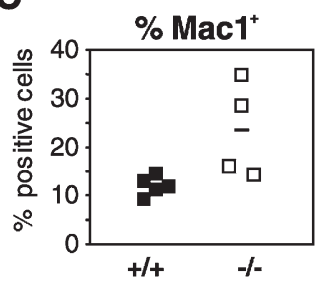

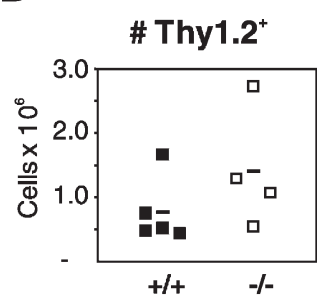

D

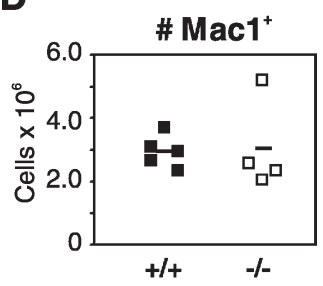

FIGURE 3 T and myeloid cell compartments of TGF $\beta 1^{-/-}$BM. Flow cytometry analysis of 3.5-week-old TGF $\beta 1^{-1-}$ mice and controls was performed using the markers indicated. Proportions (A,C) and absolute numbers $(\mathrm{B}, \mathrm{D})$ of bone marrow cells expressing $\mathrm{T}$ (Thy1.2; A,B) and myeloid (Mac1; C,D) lineage markers are shown. The Thy $1.2^{+}$cells are within the lymphoid gate. $p>0.05$ for all sample sets. 
myeloid and $\mathrm{T}$ lineage cells. However, the absolute numbers of these cells are not consistently increased in all of the mice that had an equally severe reduction in BCP. Therefore, a global disruption of the BM microenvironment seems unlikely, although our analysis does not exclude possible inhibitory effects of inflammatory/ myelopoietic foci on the $\mathrm{B}$ lineage cells in $\mathrm{TGF} \beta 1^{-/-} \mathrm{BM}$.

\section{Exogenous TGFß1 Effects upon Normal Pro- and Pre-B Cells In Vitro}

The complex pathology of the TGF $\beta 1^{-1-}$ mice and the lack of correlation between the frequency of Thy $1.2^{+}$and $\mathrm{Mac1}^{+} \mathrm{BM}$ cells and the BCP deficiency lead us to re-examine the effects of TGF $\beta 1$ on B cell development in vitro. We asked whether TGF $\beta 1$ might be beneficial for $\mathrm{B}$ cell development as suggested by the phenotype of the TGF $\beta 1^{-1-}$ mice. B $220^{+}$BM B lineage cells from normal $(\mathrm{C} 57 \mathrm{BL} / 6)$ mice were treated with TGF $\beta 1$ in the presence of IL7, a cytokine that stimulates BCP proliferation prior to the late pre-B cell stage (Hardy et al., 1991; Marshall et al., 1998). Stromal cells were not included in our system due to their ability to produce and respond to TGF $\beta$ (Dittel et al., 1993; Dittel and LeBien, 1995; Robledo et al., 1998; Olsen et al., 2001).

Intracellular (i.c.) $\mu \mathrm{HC}$ expression in $\mathrm{B}^{2} 20^{+} \mathrm{sIgM}^{-}$ $\mathrm{BCP}$ was used to identify pre-B cells recovered from cultures of IL7-stimulated B220 ${ }^{+}$BM cells (Fig. 4A). At day 3 in the control sample of IL7 alone (first column), there was a predominance of pre-B cells; however, the pro$\mathrm{B}$ cell-enriched population (i.c. $\mu \mathrm{HC}^{-} \mathrm{BCP}$ ) predominated by day 7. It should be noted that a majority of the pre-B cells in the starting population are late pre-B cells, which do not proliferate in response to IL7 (Hardy et al., 1991; Marshall et al., 1998). During the course of a weeklong culture, these cells should either expire or mature to become $\operatorname{sIgM}^{+} \mathrm{B}$ cells and thus be excluded from the analysis. Meanwhile, IL7-responsive pro-B cells accumulate and predominate in the cultures by day 7 .

Addition at day 0 of either 0.04 or $1 \mathrm{ng} / \mathrm{ml}$ TGF $\beta 1$ to the IL7 cultures resulted in little change at day 3 in the percentage of pre-B cells compared to IL7 alone (Fig. 4A). However, both treatments resulted in a consistent reduction in the total viable cell numbers recovered (not shown) corresponding to a 2 -fold reduction in both proand pre-B cell numbers at day 3 of culture [Fig. 4B (Bottom) and C, respectively].

At the later timepoints of 5 and 7 days, TGF $\beta 1$ treatment resulted in a small increase in the proportion of pre-B cells in comparison to IL7 alone (Fig. 4A). This was partially due to reductions in pro- $\mathrm{B}$ cell numbers in the presence of TGF $\beta 1$ (Fig. 4B). In contrast to reductions in pre-B cell numbers seen at day 3 of culture, treatment with $0.04 \mathrm{ng} / \mathrm{ml}$ TGF $\beta 1$ resulted in a modest increase in the numbers of pre-B cells recovered at 5 and 7 days. By contrast, treatment with $1 \mathrm{ng} / \mathrm{ml}$ TGF $\beta 1$ showed minor pre-B cell reductions at later timepoints (Fig. 4C).
The initial reductions in pre-B cells indicate that some cells are likely to be sensitive to the inhibitory effects of TGF $\beta 1$. However, the remaining pre-B cell population either has, or acquires a very high proliferative capacity, indicated by a significant 4-fold increase in the rate of growth between 3 and 7 days (Fig. 4D).

To identify the populations responsible for these distinct outcomes, we initiated similar experiments using sortpurified BM. The BP1 cell surface marker was used to subdivide normal BM into two sub-populations of $\mathrm{CD}_{1} 9^{+}$sIgM $^{-}$BCP: (1) BP1 ${ }^{-}$cells, $\sim 60 \%$ of which are i.c. $\mu \mathrm{HC}^{+}$and (2) large $\mathrm{BP} 1^{+}$cells, $\sim 90-99 \%$ i.c. $\mu \mathrm{HC}^{+}$ (not shown). Between days 3 and 7 in culture with IL7 alone, the number of $\mathrm{BP}^{-}{ }^{-}$-derived pro- and pre-B cells increased (Fig. 5A,B, respectively); in each case and at all time points, 0.04 and $1 \mathrm{ng} / \mathrm{ml}$ exogenous TGF $\beta 1$ resulted in reduced cell recovery. TGF $\beta 1$-mediated reductions in pro-B cell recoveries were also confirmed using $\mathrm{CD} 19^{+}$ Rag1 $1^{-1-}$ BM as a source of pro-B cells (not shown). In contrast to the cell growth observed with IL7 alone in cultures of $\mathrm{BP}^{-} \mathrm{BCP}$, the large $\mathrm{BP} 1^{+}$pre-B cells decreased in number between days 3 and 7 (Fig. 5C). In this context, treatment with either dose of TGF $\beta 1$ resulted in an initial decrease in pre-B cell recoveries, but subsequently, low-dose TGF $\beta 1$ treatment resulted in a net increase at days 5 and 7 of culture $(2.1 \pm 0.7$ and $3.0 \pm 0.6$-fold increase, respectively over IL7 alone; $n=3$ experiments).

Figure 5D summarizes the effects of low-dose TGF $\beta 1$ treatment where the diameter of each circle relative to the control (1.0) represents the average fold change in cell number. As seen on day 3 , each stage analyzed contains cells that are sensitive to the inhibitory effects of TGF $\beta 1$. TGF $\beta 1$-mediated reductions continue over time for $\mathrm{BP}^{-}$ $\mathrm{BCP}-$ derived pro- and pre- $\mathrm{B}$ cells, whereas the $\mathrm{BP} 1^{+}$ fraction contains cells that are positively affected by exogenous TGF $\beta 1$ treatment at a low-dose $(0.04 \mathrm{ng} / \mathrm{ml})$. At a later timepoint in the culture, $\operatorname{IgM}^{+} \mathrm{B}$ cells accumulate as well (Fig. 5D and data not shown).

\section{DISCUSSION}

We have demonstrated an age-dependent reduction in BM $\mathrm{B}$ lineage cells in TGF $\beta 1^{-1-}$ mice. The deficiency is apparent as early as Hardy's Fraction B, containing pro-B cells and extends through the immature B cell stage. The mice also have variable increases in the proportions and numbers of BM Thy $1.2^{+}$and $\mathrm{Mac1}^{+}$cells, but these do not consistently correlate with the reduction in B lineage cells. Subsequent studies of the in vitro effects of exogenous TGF $\beta 1$ on BM B lineage cells from normal mice showed reductions in pro-B cell recoveries as early as day 3 and continuing through day 7 of incubation at $\mathrm{pg} / \mathrm{ml}$ doses of TGF $\beta 1$. Although the same cultures showed an initial decrease in pre-B cell numbers, this was followed by increases at days 5 and 7 translating into a 4-fold increase in the rate of growth for the pre-B cell 
A

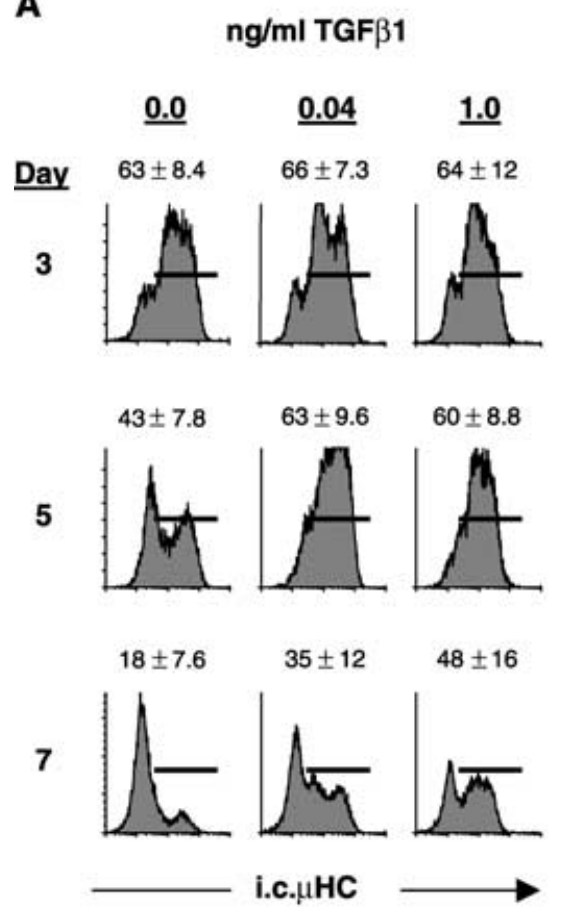

C

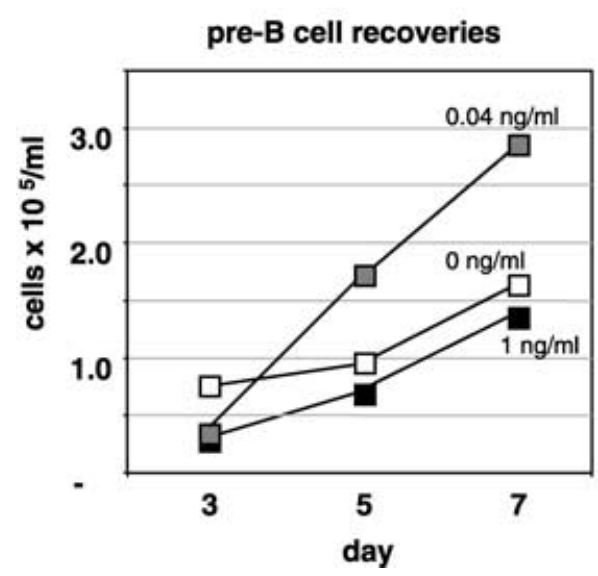

B

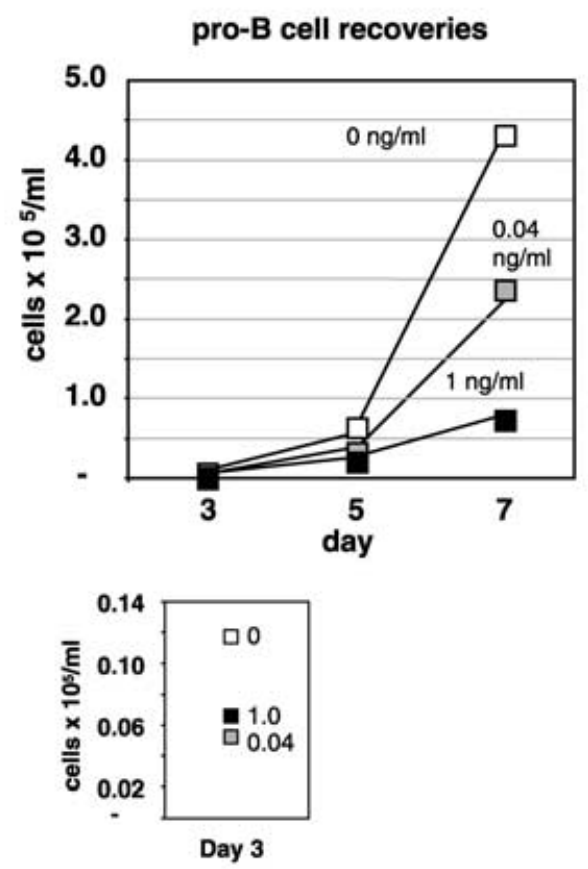

D

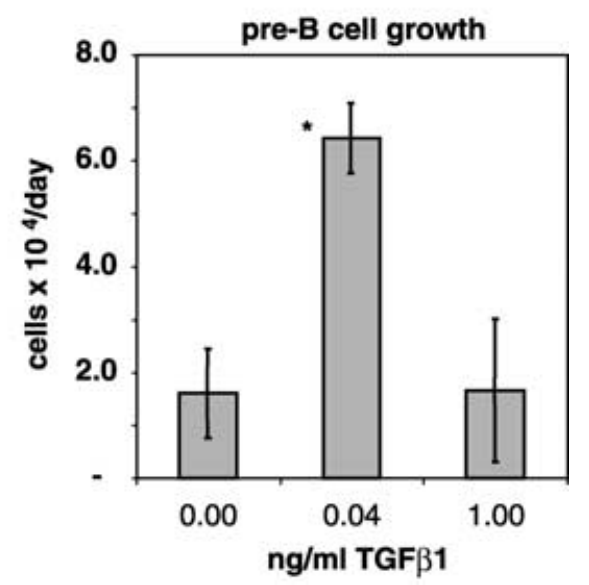

FIGURE 4 Differential effects of TGF 31 on pro- versus pre-B cells. B220 ${ }^{+}$BM cells from 4-week-old C57BL/6 mice were treated with IL7 \pm the indicated concentrations of TGF $\beta 1$. (A) Flow cytometry histograms of i.c. $\mu \mathrm{HC}$ staining within the $\mathrm{B}_{220^{+}} \mathrm{sIgM}^{-} \mathrm{BCP}$ gate of cells recovered at the indicated times. Values are the percent i.c. $\mu \mathrm{HC}^{+}$within the total viable sample ( \pm standard deviations from 3 experiments). (B) Absolute numbers of pro-B-enriched $\left(\mathrm{B} 220^{+} \mathrm{sgM}^{-}\right.$i.c. $\mu \mathrm{HC}^{-}$) cells recovered over time from one representative experiment of three. Bottom shows day 3 values on their own scale. (C) Absolute numbers of pre-B (B220 ${ }^{+} \mathrm{sIgM}^{-}$i.c. $\left.\mu \mathrm{HC}^{+}\right)$cells over time from the experiment shown in B. (D) Pre-B cell growth is indicated as the average number of cells generated per day. This was calculated as the number of cells at day 7 of culture minus the cell number at day 3 divided by 4 days. The mean \pm sample standard deviations from 3 experiments are shown. $* p=0.0015$ versus $0 \mathrm{ng} / \mathrm{ml} \mathrm{TGF} \beta 1$.

population. By sort-purification of the starting $\mathrm{BCP}$ subpopulations, the large $\mathrm{BP} 1^{+}$pre-B cell fraction was identified as containing the cells that are increased in response to TGF $\beta 1$.

Reductions in $\mathrm{BM}-\mathrm{BCP}$ in $\mathrm{TGF} \beta 1^{-1-}$ mice were unanticipated because TGF $\beta$ had been previously shown to have inhibitory effects upon the B lineage in vitro (Lee et al., 1987; Kincade et al., 1989; Lee et al., 1989; Rehmann and LeBien, 1994; Kee et al., 2001). The reductions in vivo may thus be due to an unrecognized necessity for a TGF $\beta$ receptor signal directly upon B lineage cells. Alternatively, effects secondary to the TGF $\beta 1$ deficiency, e.g. soluble factors produced by infiltrating inflammatory cells, circulating prostaglandins or sex hormones (Kincade et al., 1989; Wang et al., 1995; Kincade et al., 2000), which could be directly regulated by TGF $\beta 1$ or induced in response to inflammatory stress may be responsible. Alterations in cellular adhesion may also contribute to dysregulated B lymphopoiesis in the BM (Dittel et al., 1993; Dittel and LeBien, 1995).

B cell development is apparently normal in very young (1.5 week) $\mathrm{TGF}^{-1-}$ mice and deteriorates thereafter. 
A
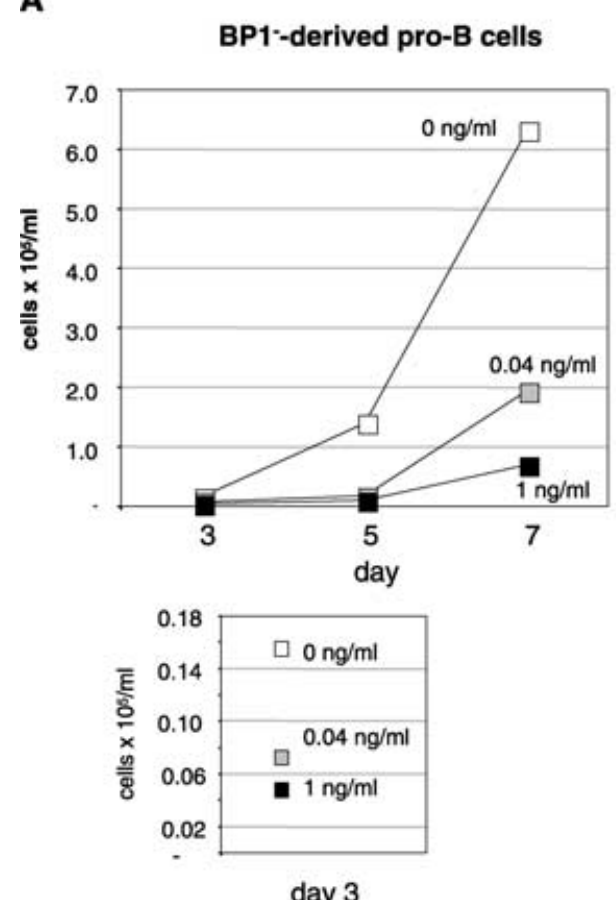

C

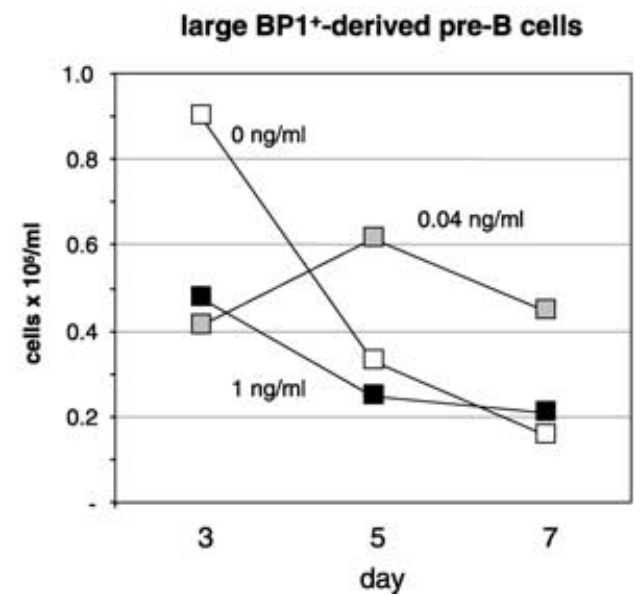

B

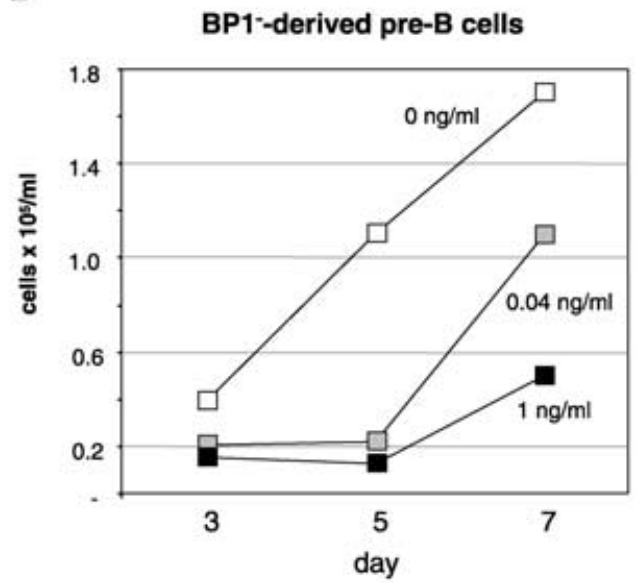

D

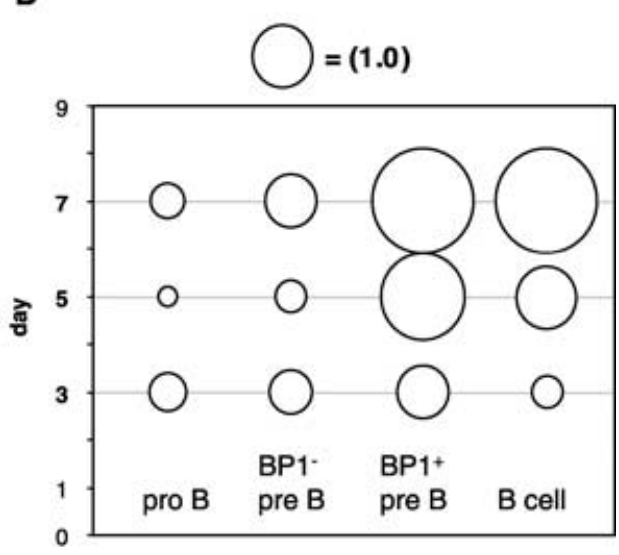

FIGURE 5 Differential sensitivity of BCP subsets to TGF 31 . CD19 ${ }^{+} \mathrm{sIgM}^{-} \mathrm{BCP}$ from $\mathrm{C} 57 \mathrm{BL} / 6$ mice were sort-purified into $\mathrm{BP} 1^{-}$and large $\mathrm{BP} 1^{+}$ subsets. The sorted cells were cultured, harvested, and phenotyped as in Fig. 4. (A) Numbers of pro-B cells derived from the BP1 ${ }^{-}$sub-population from a representative experiment. (B) Numbers of pre-B cells derived from the same BP1 ${ }^{-}$sub-population. (C) Pre-B cells derived from the large, BP1 ${ }^{+}$subpopulation. Results in A-C are representative of 3 experiments. (D) Summary of relative effects of low-dose TGF $\beta 1$ upon B cell development over time in culture. The size of each circle represents the effect of low-dose TGF $\beta 1$ in IL7 as a fold change compared to IL7 alone ( = 1.0). Stages of B cell development examined in culture are on the $X$ axis, whereas time in culture progresses from bottom-to-top on the $Y$ axis.

This age dependency may be due to maternal TGFß1, acquired in utero or during nursing, compensating early in life for the lack of de novo production (Letterio et al., 1994) and delaying the onset of defects in B lymphopoiesis. Alternatively, BCP derived from older mice may have a differential sensitivity to TGF $\beta 1$ in comparison to those generated earlier in life, as differences have been observed for BCP at different stages of ontogeny (Kearney et al., 1997; Hardy et al., 2000; Igarashi et al., 2001). In either case, the mature B cells found in the BM and periphery of 3- to 5-week old TGF $\beta 1^{-1-}$ mice are likely generated at an earlier age when B cell development is unaffected by the TGF $\beta 1$ mutation.

Thy $1.2^{+} \mathrm{BM}$ cells were examined in TGF $\beta 1^{-1-}$ mice because activated $\mathrm{T}$ cells have been shown to be responsible for the systemic inflammation that these mice acquire (Kulkarni and Karlsson, 1993; Diebold et al., 1995; Kulkarni et al., 1995; Borkowski et al., 1996; Letterio et al., 1996; McCartney-Francis et al., 1997; Nakabayashi et al., 1997; Kobayashi et al., 1999; McLennan et al., 2000). $\mathrm{Mac1}^{+}$myeloid lineage BM cells were also examined because enhanced myelopoiesis, 
an apparent consequence of TGF $\beta 1$ deficiency (Boivin et al., 1995; Letterio et al., 1996), correlates with suppressed B lymphopoiesis (Buske et al., 2001; Fraker and King, 2001). Macrophages are a component of the cellular infiltrate seen in other tissues, such as the heart, in these mice (Boivin et al., 1995; Kulkarni et al., 1995; Letterio et al., 1996), and their activation products, including interleukin 1 and the interferons, have been shown to be inhibitory for BCP (Dorshkind, 1988; Wang et al., 1995).

The analysis of $\mathrm{T}$ and myeloid cells in individual $\mathrm{TGF} \beta 1^{-1-}$ mice indicates variable alterations in the cellular composition of the BM; however, there was no consistent correlation with $\mathrm{BCP}$ reductions. Moreover, when TGF $\beta 1^{-1-}$ mice are rendered deficient in $\mathrm{CD} 8^{+} \mathrm{T}$ cells, by backcrossing to a $\beta 2$-microglobulin (MHC Class I) deficient genetic background, which prevents the T cell-mediated inflammatory disease, total $\mathrm{B} 220^{+} \mathrm{BM} \mathrm{B}$ lineage cells are still reduced (Kobayashi et al., 1999). This deficiency in B lineage cells, as in our studies, is specific to the BM, and is not observed in the spleen. We have attempted to address the role of the T cell-mediated inflammatory response in the BCP deficiency by breeding $\mathrm{TGF} \beta 1^{-1-}$ and $\mathrm{TCR} \alpha^{-1-}$ mice. However, no doubly homozygous mutant offspring were obtained.

Another approach has been to examine B cell development in a model where only B lineage cells are unresponsive to TGF $\beta$. In mice conditionally gene-targeted for the T $\beta R I I$ subunit of the TGF $\beta$ receptor specifically in $\mathrm{B}$ cells, the early B lineage cells in the BM were reportedly unchanged in comparison to the controls (Cazac and Roës, 2000). However, the CD19cre deletion system used in these studies is less efficient in late pre-B cells $(75-80 \%)$ than in splenic B cells (90-95\%) (Rickert et al., 1997). It is thus unclear whether and at what efficiency T $\beta$ RII deletion occurs at earlier stages of B cell development, since TGF $\beta$ responsiveness was not examined in the BM B lineage cells of these mice. However, in the periphery, where B lineage cells had defective TGF $\beta$ receptor signaling, populations of mature B lymphocytes were increased, as were serum levels of anti-nuclear antibodies indicating a direct inhibitory role for TGF $\beta$ on B lineage cells at later stages (Cazac and Roës, 2000).

If $\mathrm{BCP}$ deficiencies in TGF $\beta 1^{-1-}$ mice are due to a requirement for a direct TGF $\beta$ receptor signal on these cells, we reasoned that using a defined culture system with rIL7 and purified BM B lineage cells from normal mice, we could identify sub-populations that benefit from exposure to exogenous TGF 1 . In IL7-containing cultures, pro-B cell recoveries were consistently decreased by low-dose TGF $\beta 1$ treatment. An often-overlooked population of i.c. $\mu \mathrm{HC}^{+}$pre-B cells, included in Hardy's Fraction B, is also reduced by TGF $\beta 1$ in culture. By contrast, the numbers of pre-B cells derived from large $\mathrm{BP}^{+} \mathrm{BCP}$ were increased. Notably, the more severe in vivo $\mathrm{BCP}$ reductions in $\mathrm{TGF} \beta 1^{-1-}$ mice begin in Fraction $\mathrm{C}$, which corresponds to the large $\mathrm{BP} 1^{+}$pre- $\mathrm{B}$ cells in our cultures.
The effects of TGF $\beta$ on cell cycle and apoptosis may provide an alternative explanation for our in vitro data. Pro-B cells proliferating in response to IL-7 eventually mature into i.c. $\mu \mathrm{HC}^{+}$pre-B cells and then exit cell cycle. At low doses, TGF $\beta$ may inhibit proliferation of the pro-B cells, which then may complete IgH chain gene rearrangement and express $\mu \mathrm{HC}$. This outcome would result in the observed decrease in pro-B cells and increase in pre-B cells. Higher doses of TGF $\beta$ may induce pro-B cell apoptosis, thus accounting for the decrease in both pro- and pre-B cells. However, this interpretation does not account for the net increase in pre-B cells with low dose TGF- $\beta$ in cultures initiated with large $\mathrm{BP} 1^{+}$cells, $90-99 \%$ of which already express $\mu \mathrm{HC}$.

In conclusion, TGF $\beta 1$ influences B cell development in multiple ways including directly inhibiting pro-B cell/early pre-B cell populations. The $\mathrm{BP} 1^{+}$pre-B cells are unique among $\mathrm{B}$ lineage cells in their positive response to exogenous TGF $\beta 1$. It is currently unclear why the large pre-B cells respond to TGF $\beta$ in this way. It has been suggested that the stability of the preBCR, which varies depending upon the $\mu \mathrm{HC}$ variable region, may regulate cellular viability and proliferation (Melchers et al., 2000). A pre-B cell with a well-fitting preBCR would receive proliferative/viability signals via the receptor itself, and consequently the cell could be changed in other ways to give it the greatest advantage over cells with a poorly fitting preBCR. Differential responsiveness to TGF $\beta$ may be one such phenotypic change and would be advantageous for expanding the numbers of these positively selected pre-B cells.

\section{Acknowledgements}

We thank Max D. Cooper, John F. Kearney, Flavius Martin and Robert P. Stephan for discussion and assistance, Larry Gartland for cell sorting, Jeff Nyswaner for animal care, and Ann Brookshire for editorial assistance. Supported by National Institutes of Health Grants AI48098 and HD36312; D.A. Kaminski was supported by T32AI07051-26.

\section{References}

Boivin, G.P., O’Toole, B.A., Orsmby, I.E., Diebold, R.J., Eis, M.J., Doetschman, T. and Kier, A.B. (1995) "Onset and progression of pathological lesions in transforming growth factor- $\beta$ 1-deficient mice", American Journal of Pathology 146, 276-288.

Bonyadi, M., Rusholme, S.A., Cousins, F.M., Su, H.C., Biron, C.A., Farrall, M. and Akhurst, R.J. (1997) "Mapping of a major genetic modifier of embryonic lethality in TGF $\beta 1$ knockout mice", Nature Genetics 15, 207-211.

Borghesi, L.A., Smithson, G. and Kincade, P.W. (1997) "Stromal cell modulation of negative regulatory signals that influence apoptosis and proliferation of B lineage lymphocytes", The Journal of Immunology 159, 4171-4179.

Borkowski, T.A., Letterio, J.J., Farr, A.G. and Udey, M.C. (1996) "A role for endogenous transforming growth factor $\beta 1$ in Langerhans cell biology: the skin of transforming growth factor $\beta 1$ null mice is devoid of epidermal Langerhans cells", Journal of Experimental Medicine 184, 2417-2422. 
Bottinger, E.P., Letterio, J.J. and Roberts, A.B. (1997) "Biology of TGF- $\beta$ in knockout and transgenic mouse models", Kidney International 51, 1355-1360.

Buske, C., Feuring-Buske, M., Antonchuk, J., Rosten, P., Hogge, D.E., Eaves, C.J. and Humphries, R.K. (2001) "Overexpression of HOXA10 perturbs human lymphomyelopoiesis in vitro and in vivo", Blood 97, 2286-2292.

Candeias, S., Muegge, K. and Durum, S.K. (1997) "IL-7 receptor and VDJ recombination: trophic versus mechanistic actions", Immunity $\mathbf{6}$, 501-508.

Cazac, B.B. and Roës, J. (2000) "TGF- $\beta$ receptor controls B cell responsiveness and induction of IgA in vivo", Immunity 13 443-451.

Christ, M., McCartney-Francis, N.L., Kulkarni, A.B. and Ward, J.M. (1994) "Immune dysregulation in TGF- $\beta 1$-deficient mice", Journal of Immunology 153, 1936-1946.

Corcoran, A.E., Riddell, A., Krooshoop, D. and Venkitaraman, A.R. (1998) "Impaired immunoglobulin gene rearrangement in mice lacking the IL-7 receptor", Nature 391, 904-907.

Dang, H., Geiser, A.G., Letterio, J.J., Nakabayashi, T., Kong, L., Fernandes, G. and Talal, N. (1995) "SLE-like autoantibodies and Sjogren's syndrome-like lymphoproliferation in TGF- $\beta$ knockout mice", Journal of Immunology 155, 3205-3212.

Diebold, R.J., Eis, M.J., Yin, M., Ormsby, I., Boivin, G.P., Darrow, R.J., Safitz, J.E. and Doetchman, T. (1995) "Early-onset multifocal inflammation in the transforming growth factor $\beta 1$-null mouse is lymphocyte-mediated", Proceedings of the National Academy of Sciences of the United States of America 92, 12215-12219.

Dickson, M.C., Martin, J.S., Cousins, F.M., Kulkarni, A.B., Karlsson, S and Akhurst, R.J. (1995) "Defective haematopoiesis and vasculogenesis in transforming growth factor- $\beta 1$ knock out mice", Development 121, 1845-1854.

Dittel, B.N. and LeBien, T.W. (1995) "Reduced expression of vascular cell adhesion molecule-1 on bone marrow stromal cells isolated from marrow transplant recipients correlates with a reduced capacity to support human B lymphopoiesis in vitro", Blood 86, 2833-2841.

Dittel, B.N., McCarthy, J.B., Wayner, E.A. and LeBien, T.W. (1993) "Regulation of human B-cell precursor adhesion to bone marrow stromal cells by cytokines that exert opposing effects on the expression of vascular cell adhesion molecule-1 (VCAM-1)", Blood 81, 2272-2282.

Dorshkind, K. (1988) "IL-1 inhibits B cell differentiation in long term bone marrow cultures", Journal of Immunology 141, 531-538.

Fraker, P.J. and L.E. (2001) "A distinct role for apoptosis in the changes in lymphopoiesis and myelopoiesis created by deficiencies in zinc", FASEB Journal 15, 2572-2578.

Gimble, J.M., Pietrangeli, C., Henley, A., Dorheim, M.A., Silver, J., Namen, A., Takeichi, M., Goridis, C. and Kincade, P.W. (1989) "Characterization of murine bone marrow and spleen-derived stromal cells: analysis of leukocyte marker and growth factor mRNA transcript levels", Blood 74, 303-311.

van Ginkel, F.W., Wahl, S.W., Kearney, J.F., Kweon, M.N., Fujihashi, K. Burrows, P.D., Kiyono, H. and McGhee, J.R. (1999) "Parital IgA deficiency with increased Th2-type cytokines in TGF- $\beta 1$ knockou mice", The Journal of Immunology 163, 1951-1957.

Hardy, R.R. (1992) "Variable gene usage, physiology and development of Ly- $1^{+}\left(\mathrm{CD}^{+}\right)$B cells", Current Opinion in Immunology 4, 181-185.

Hardy, R.R., Carmack, C.E., Shinton, S.A., Kemp, J.D. and Hayakawa K. (1991) "Resolution and characterization of pro-B and pre-pro-B cell stages in normal mouse bone marrow", Journal of Experimental Medicine 173, 1213-1225.

Hardy, R.R., Wasserman R., Li, Y.S., Shinton, S.A., Hayakawa, K. (2000) "Response by B cell precursors to pre-B receptor assembly: differences between fetal liver and bone marrows." Current Topics in Microbiology and Immunology 252, 25-30.

Hocevar, B.A. and Howe, P.H. (1998) "Mechanisms of TGF- $\beta$-induced cell cycle arrest", Mineral and Electrolyte Metabolism 24, 131-135.

Igarashi, H., Kouro, T., Yokota, T., Comp, P.C. and Kincade, P.W. (2001) "Age and stage dependency of estrogen receptor expression by lymphocyte precursors", Proceedings of the National Academy of Sciences of the United States of America 98, 15131.

Itoh, N., Yasunaga, M., Hirashaima, M., Yoshida, O. and Nishikawa, S.I. (1996) "Role of IL-7 and KL in activating molecules controlling the G1/S transition of B precursor cells", International Immunology $\mathbf{8}$ $317-323$

Kaartinen, V., Voncken, J.W., Shuler, C., Warburton, D., Bu, D., Heisterkamp, N. and Groffen, J. (1995) “Abnormal lung development and cleft palate in mice lacking TGF- $\beta 3$ indicates defects of epithelial-mesenchymal interaction", Nature Genetics 11, 415-421.

Kearney, J.F., Won, W.J., Benedict, C., Moratz, C., Zimmer, P., Oliver, A., Martin, F. and Shu, F. (1997) "B cell development in mice", International Reviews of Immunology 15, 207-241.

Kee, B.L., Rivera, R.R. and Murre, C. (2001) "Id3 inhibits B lymphocyte progenitor growth and survival in response to TGF $\beta$ ", Nature Immunology 2, 242-247.

Kim, P.H. and Kagnoff, M.F. (1990) "Transforming growth factor $\beta 1$ increases $\operatorname{IgA}$ isotype switching at the clonal level", Journal of Immunology 145, 3773-3778.

Kim, L.T. and Yamada, K.M. (1997) "The regulation of expression of integrin receptors", Proceedings of the Society for Experimental Biology and Medicine 214, 123-131.

Kincade, P.W., Lee, G., Pietrangeli, C.E., Hayashi, S. and Gimble, J.M. (1989) "Cells and molecules that regulate B lymphopoiesis in bone marrow", Annual Review of Immunology 7, 111-143.

Kincade, P.W., Medina, K.L., Payne, K.J., Rossi, M.I., Tudor, K.S., Yamashita, Y. and Kouro, T. (2000) "Early B-lymphocyte precursors and their regulation by sex steroids", Immunological Reviews $\mathbf{1 7 5}$, $128-137$.

King, A.G., Wierda, D. and Landreth, K.S. (1988) "Bone marrow stromal cell regulation of B-lymphopoiesis. I. The role of macrophages, IL-1, and IL-4 in pre-B cell maturation", Journal of Immunology 141, 2016-2026.

Kobayashi, S., Yoshida, K., Ward, J.M., Letterio, J.J., Longenecker, G., Yaswen, L., Mittleman, B., Mozes, E., Roberts, A.B., Karlsson, S. and Kulkarni, A.B. (1999) " $\beta 2$-microglobulin-deficient background ameliorates lethal phenotype of the TGF- $\beta 1$ null mouse", Journal of Immunology 163, 4013-4019.

Kulkarni, A.B. and Karlsson, S. (1993) "Transforming growth factor- $\beta 1$ knockout mice. A mutation in one cytokine gene causes a dramatic inflammatory disease", American Journal of Pathology 143, 3-9.

Kulkarni, A.B., Huh, C.G., Becker, D., Geiser, A., Lyght, M., Flanders, K.C., Roberts, A.B., Sporn, M.B., Ward, J.M. and Karlsson, S. (1993) "Transforming growth factor $\beta 1$ null mutation in mice causes excessive inflammatory response and early death", Proceedings of the National Academy of Sciences of the United States of America 90, 770-774.

Kulkarni, A.B., Ward, J.M., Yaswen, L., Mackall, C.L., Bauer, S.R., Huh, C.G., Gress, R.E. and Karlsson, S. (1995) "Transforming growth factor- $\beta 1$ null mice. An animal model for inflammatory disorders", American Journal of Pathology 146, 264-275.

Larsson, J., Goumans, M.J., Sjostrand, L.J., van Rooijen, M.A., Ward, D., Leveen, P., Xu, X., ten Dijke, P., Mummery, C.L. and Karlsson, S. (2001) "Abnormal angiogenesis but intact hematopoietic potential in TGF- $\beta$ type I receptor-deficient mice", EMBO Journal 20, $1663-1673$.

Lebman, D.A., Lee, F.D and Coffman, R.L. (1990) "Mechanism for transforming growth factor $\beta$ and IL-2 enhancement of IgA expression in lipopolysaccharide-stimulated B cell cultures", Journal of Immunology 144, 952-959.

Lee, G., Ellingsworth, L.R., Gillis, S., Wall, R. and Kincade, P.W. (1987) " $\beta$ transforming growth factors are potential regulators of B lymphopoiesis", Journal of Experimental Medicine 166, 1290-1299.

Lee, G., Namen, A.E., Gillis, S., Ellingsworth, L.R. and Kincade, P.W. (1989) "Normal B cell precursors responsive to recombinant murine IL-7 and inhibition of IL-7 activity by transforming growth factor- $\beta$ ", Journal of Immunology 142, 3875-3883.

Letterio, J.J. and Roberts, A.B. (1998) "Regulation of immune responses by TGF- $\beta$ ", Annual Review of Immunology 16, 137-161.

Letterio, J.J., Geiser, A.G., Kulkarni, A.B., Roche, N.S., Sporn, M.B. and Roberts, A.B. (1994) "Maternal rescue of transforming growth factor$\beta 1$ null mice", Science 264, 1936-1938.

Letterio, J.J., Geiser, A.G., Kulkarni, A.B., Dang, H., Kong, L., Nakabayashi, T., Mackall, C.L., Gress, R.E. and Roberts, A.B. (1996) "Autoimmunity associated with TGF- $\beta 1$ deficiency in mice is dependent on MHC Class II antigen expression", The Journal of Clinical Investigation 98, 2109-2119.

Li, Y.S., Hayakawa, K. and Hardy, R.R. (1993) "The regulated expression of B lineage associated genes during B cell differentiation in bone marrow and fetal liver", Journal of Experimental Medicine 178, 951-960.

Li, Y.S., Wasserman, R., Hayakawa, K. and Hardy, R.R. (1996) "Identification of the earliest B lineage stage in mouse bone marrow", Immunity 5, 527-535. 
Marshall, L.J., Fleming, H.E., Wu, G.E. and Paige, C.J. (1998) "Modulation of the IL-7 dose-response threshold during pro B cell differentiation is dependent on pre B cell receptor expression", The Journal of Immunology 161, 6038-6045.

Martin, J.S., Dickson, M.C., Cousins, F.M., Kulkarni, A.B., Karlsson, S. and Akhurst, R.J. (1995) "Analysis of homozygous TGF $\beta 1$ null mouse embryos demonstrates defects in yolk sac vasculogenesis and hematopoiesis", Annals of the New York Academy of Sciences $\mathbf{7 5 2}$ 300-308.

Massague, J., Cheifetz, S., Laiho, M., Ralph, D.A., Weis, F.M. and Zentella, A. (1992) "Transforming growth factor- $\beta$ ", Cancer Surveys 12, 81-103.

McCartney-Francis, N.L. and Wahl, S.M. (1994) "Transforming growth factor $\beta$ : a matter of life and death", Journal of Leukocyte Biology $\mathbf{5 5}$ 401-409.

McCartney-Francis, N.L., Mizel, D.E., Frazier-Jessen, M., Kulkarni, A.B., McCarthy, J.B. and Wahl, S.M. (1997) "Lacrimal gland inflammation is responsible for ocular pathology in TGF- $\beta 1$ null mice", American Journal of Pathology 151, 1281-1288.

McLennan, I.S., Poussart, Y. and Koishi, K. (2000) "Development of skeletal muscles in transforming growth factor- $\beta 1$ (TGF- $\beta 1$ ) nullmutant mice", Developmental Dynamics 217, 250-256.

Meffre, E., Casellas, R. and Nussenzweig, M.C. (2000) "Antibody regulation of B cell development", Nature Immunology 1, 379-385.

Melchers, F., ten Boekel, E., Seidl, T., Kong, X.C., Yamagami, T., Onishi K., Shimizu, T., Rolink, A.G. and Andersson, J. (2000) "Repertoire selection by pre-B-cell receptors and B-cell receptors, and genetic control of B-cell development from immature to mature B cells", Immunological Reviews 175, 33-46.

Nakabayashi, T., Letterio, J.J., Geiser, A.G., Kong, L., Ogawa, N., Zhao, W., Koike, T., Fernandes, G., Dang, H. and Talal, N. (1997) "Upregulation of cytokine mRNA, adhesion molecule proteins, and MHC class II proteins in salivary glands of TGF- $\beta 1$ knockout mice: MHC class II is a factor in the pathogenesis of TGF- $\beta 1$ knockout mice", Journal of Immunology 158, 5527-5535.

Olsen, N.J., Gu, X. and Kovacs, W.J. (2001) "Bone marrow stromal cells mediate androgenic suppression of B lymphocyte development", Journal of Clinical Investigation 108, 1697-1704.

Osmond, D.G. (1991) "Proliferation kinetics and the lifespan of B cells in central and peripheral lymphoid organs", Current Opinion in Immunology 3, 179-185.

Papavasiliou, F., Jankovic, M., Gong, S. and Nussenzweig, M.C. (1997) "Control of immunoglobulin gene rearrangements in developing B cells", Current Opinion in Immunology 9, 233-238.

Peschon, J.J., Morrissey, P.J., Grabstein, K.H., Ramsdell, F.J., Maraskovsky, E., Gliniak, B.C., Park, L.S., Ziegler, S.F., Williams, D.E., Ware, C.B., et al., (1994) "Early lymphocyte expansion is severely impaired in interleukin 7 receptor-deficient mice", Journa of Experimental Medicine 180, 1955-1960.

Ravitz, M.J. and Wenner, C.E. (1997) "Cyclin-dependent kinase regulation during $\mathrm{G} 1$ phase and cell cycle regulation by TGF- $\beta$ ", Advances in Cancer Research 71, 165-207.
Rehmann, J.A. and LeBien, T.W. (1994) "Transforming growth factor- $\beta$ regulates normal human pre-B cell differentiation", International Immunology 6, 315-322.

Rickert, R.C., Röes, J. and Rajewsky, K. (1997) "B lymphocyte-specific, Cre-mediated mutagenesis in mice", Nucleic Acids Research 25, $1317-1318$.

Rifkin, D.B., Kojima, S., Abe, M. and Harpel, J.G. (1993) "TGF- $\beta$ : structure, function, and formation", Thrombosis and Haemostasis $\mathbf{7 0}$, $177-179$.

Roberts, A.B., McCune, B.K. and Sporn, M.B. (1992) "TGF- $\beta$ : regulation of extracellular matrix", Kidney International 41, $557-559$.

Robledo, M.M., Sanz-Rodriguez, F., Hidalgo, A. and Teixido, J. (1998) "Differential use of very late antigen-4 and -5 integrins by hematopoietic precursors and myeloma cells to adhere to transforming growth factor- $\beta 1$-treated bone marrow stroma", Journal of Biological Chemistry 273, 12056-12060.

Rolink, A.G., ten Boekel, E., Yamagami, T., Ceredig, R., Andersson, J. and Melchers, F. (1999) "B cell development in the mouse from early progenitors to mature B cells", Immunology Letters 68, 89-93.

Sanford, L.P., Ormsby, I., Gittenbergerdegroot, A.C., Sariola, H., Friedman, R., Boivin, G.P., Cardell, E.L. and Doetschman, T. (1997) "TGF- $\beta 2$ knockout mice have multiple developmental defects that are non-overlapping with other TGF- $\beta$ knockout phenotypes", Development 124, 2659-2670.

Shockett, P. and Stavnezer, J. (1991) "Effect of cytokines on switching to $\operatorname{IgA}$ and alpha germline transcripts in the B lymphoma I.29 mu. Transforming growth factor- $\beta$ activates transcription of the unrearranged C alpha gene", Journal of Immunology 147, 4374-4383.

Shull, M.M., Ormsby, I., Kier, A.B., Pawlowski, S, Diebold, R.J., Yin, M. and Allen, R. (1992) "Targeted disruption of the mouse transforming growth factor- $\beta 1$ gene results in multifocal inflammatory disease", Nature 359, 693-699.

Tudor, K.S., Payne, K.J., Yamashita, Y. and Kincade, P.W. (2000) "Functional assessment of precursors from murine bone marrow suggests a sequence of early B lineage differentiation events", Immunity 12, 335-345.

Wahl, S.M. (1994) "Transforming growth factor $\beta$ : the good, the bad, and the ugly", Journal of Experimental Medicine 180, $1587-1590$.

Wang, J., Lin, Q., Langston, H. and Cooper, M.D. (1995) "Resident bone marrow macrophages produce type 1 interferons that can selectively inhibit interleukin-7-driven growth of B lineage cells", Immunity 3, 475-484.

Wasserman, R., Li, Y.S. and Hardy, R.R. (1997) "Down-regulation of terminal deoxynucleotidyl transferase by Ig heavy chain in B lineage cells", Journal of Immunology 158, 1133-1138.

Yaswen, L., Kulkarni, A.B., Fredrickson, T., Mittleman, B., Schiffman, R., Payne, S., Longenecker, G., Mozes, E. and Karlsson, S. (1996) "Autoimmune manifestations in the transforming growth factor- $\beta 1$ knockout mouse", Blood 87, 1439-1445. 


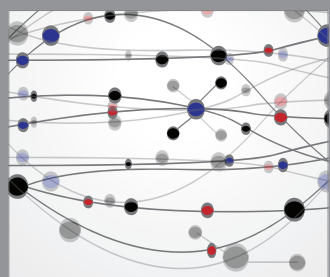

The Scientific World Journal
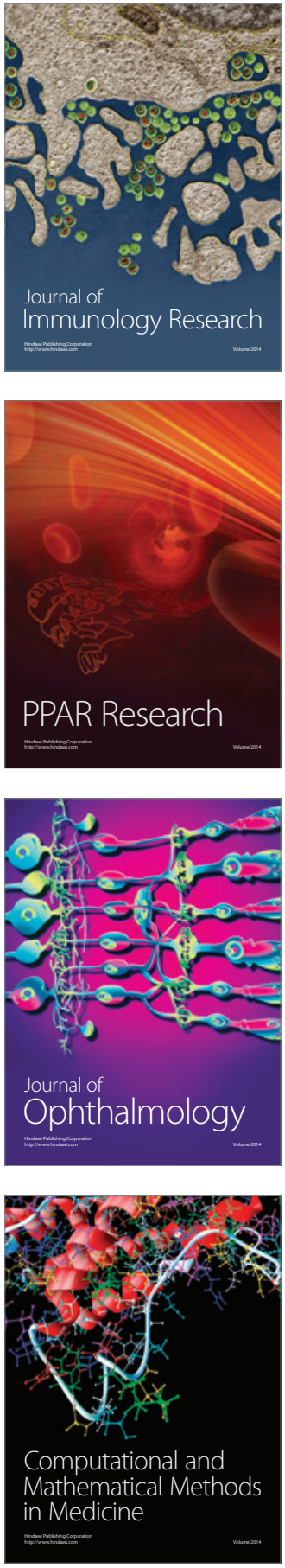

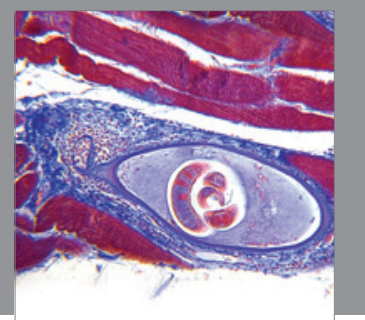

Gastroenterology

Research and Practice
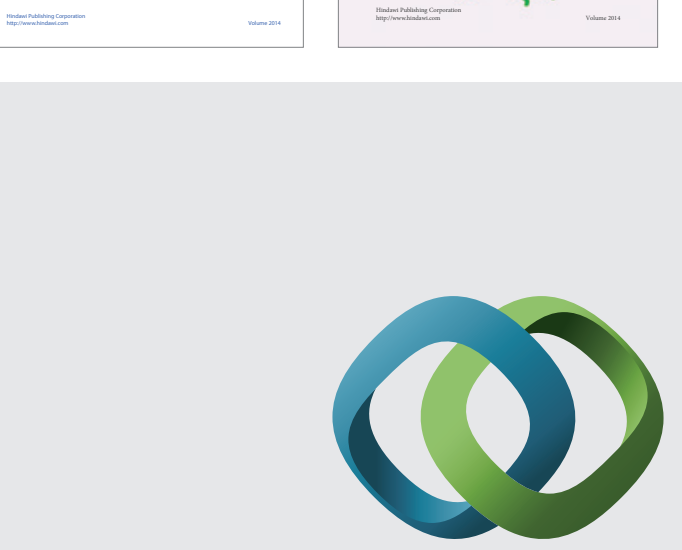

\section{Hindawi}

Submit your manuscripts at

http://www.hindawi.com
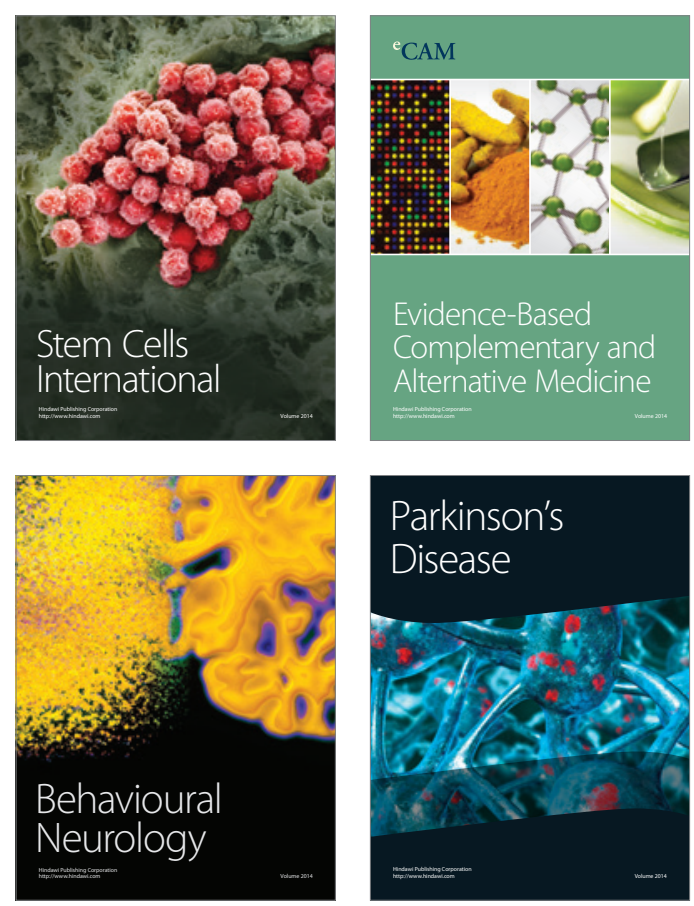

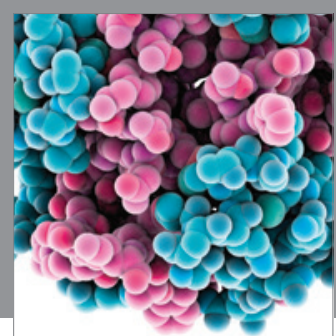

Journal of
Diabetes Research

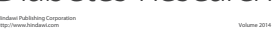

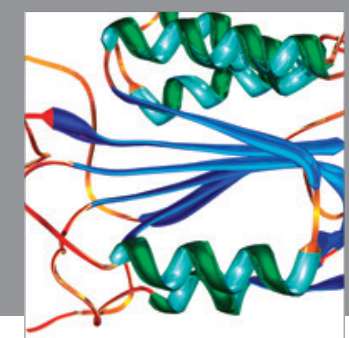

Disease Markers
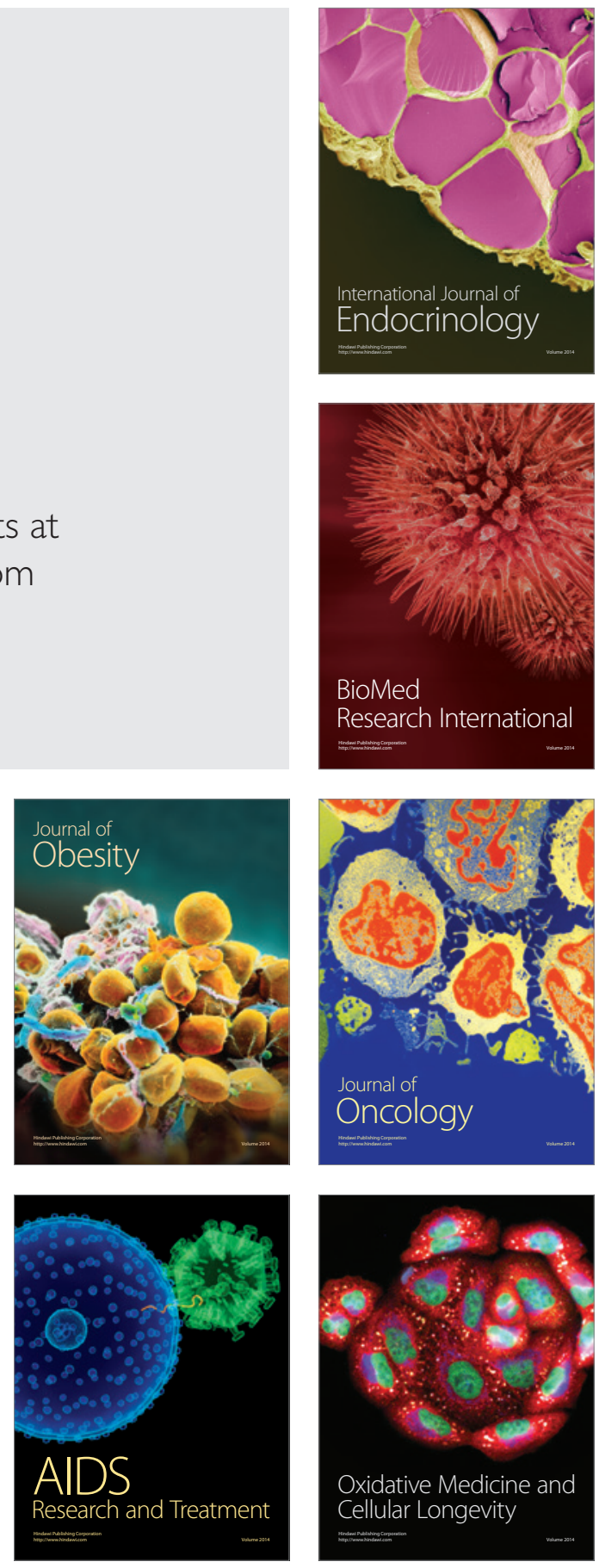